\title{
Identification of a rat protein similar to the human decidua-associated protein (hDP) 200
}

\author{
R. Halperin ${ }^{1}$, E. Hadas ${ }^{2}$, N. Shinar ${ }^{3}$, P. F. Kraicer ${ }^{3}$ and D. Schneider ${ }^{1}$ \\ ${ }^{1}$ Department of Obstetrics and Gynecology, Assaf Harofeh Medical Center, Zerifin 70300, affiliated to the \\ Sackler Faculty of Medicine, Tel Aviv University, Tel Aviv, Israel; ${ }^{2}$ Pepto Laboratories, Science Based \\ Industrial Park, Ness Ziona 76100, Israel; and ${ }^{3}$ Department of Zoology. George S. Wise Faculty of Life \\ Sciences, Tel Aviv University, Tel Aviv 69978, Israel
}

\begin{abstract}
The possibility of using the rat as an experimental model for the further research of human decidua-associated protein (hDP) 200 was examined. A rat protein similar to the hDP 200 was identified and immunoaffinity purified, using a monoclonal antibody recognizing hDP 200. The protein was named rat decidua-associated protein (rDP) 200 . The abundance of rDP 200 in endometrial tissue extracts and in uterine washings was measured throughout the oestrous cycle and on consecutive days, starting the day after the rats mated until the day after the blastocyst implantation. The results indicate that the highest concentration of rDP 200 in uterine washings may be related to oestrogen control and probably to the implantation process. Further studies are needed to confirm these findings.
\end{abstract}

\section{Introduction}

Knowledge concerning the role of decidualization of the uterine endometrium in implantation and pregnancy in humans is scarce. Assuming that some of the functions of the decidua are mediated by secretory proteins, studies have been directed toward the comprehensive identification of such proteins. We have previously described the identification and immunopurification of a human decidua-associated protein (hDP) with an apparent molecular mass of $200 \mathrm{kDa}$, and named it hDP 200 (Halperin et al, 1990).

According to polyacrylamide gel electrophoretic analysis under reducing conditions, hDP 200 is composed of two different polypeptide chains, of apparent molecular mass $55 \mathrm{kDa}$ and $25 \mathrm{kDa}$, while under non-reducing conditions the hDP 200 appears at a molecular mass of $200 \mathrm{kDa}$ (Halperin et al., 1990). N-terminal sequencing of the $55 \mathrm{kDa}$ and $25 \mathrm{kDa}$ chains has revealed that they are an immunoglobulin heavy chain and a human kappa light chain, respectively (Halperin et al., 1994). The sequence of the two chains, together with the ability of the hDP 200 molecules to complex with other immunoglobulins (Halperin et al., 1996a), suggests that hDP 200 is an immunoglobulin, apparently a monoclonal rheumatoid factor (Halperin et al, 1994). Although the role of this protein has not been determined, it has been isolated from endometrial tissue as well as from intraluminal fluid throughout the menstrual cycle (Halperin et al., 1990, 1996b; Golan et al., 1994). Furthermore, implantation and pregnancy rates show a significantly positive correlation with the concentration of hDP 200 in the uterine fluid, measured just before IVF embryo transfer during IVF procedures (Halperin et al., 1995b).

The possible physiological role of hDP 200 in the process of decidua differentiation and implantation was investigated

Received 20 March 1997. further using the rat as an experimental model. In the current paper, immunoaffinity purification and quantitation of a rat protein similar to the hDP 200 , identified by using the monoclonal antibody recognizing hDP 200, are described.

\section{Materials and Methods}

\section{Animals}

Wistar strain albino rats that were not inbred were obtained from the animal breeding facility in Tel Aviv University. The rats used were 10-15 week old females and weighed between 180 and $230 \mathrm{~g}$. They were housed in air-conditioned rooms with an artificial photoperiod of $14 \mathrm{~h}$. Vaginal smears were examined daily for two or three cycles before treatment.

\section{Preparation of decidual tissue}

Rats were ovariectomized 2 weeks before hormonal preparation. Hormonal treatment included injection of oestradiol and progesterone (Sigma, Rehovot) in sesame oil subcutaneously, according to the following schedule: day $1,100 \mathrm{mg}$ oestradiol; days 2 and 3,4 mg progesterone; day 4, $200 \mathrm{mg}$ oestradiol and $4 \mathrm{mg}$ progesterone. The decidual reaction was induced by injecting $15 \mu \mathrm{l}$ sesame oil into both uterine horns $12 \mathrm{~h}$ after the last hormonal injection. The rats were killed $72 \mathrm{~h}$ later, and the decidual tissue was extruded from the removed uteri. The tissues were homogenized in one volume of cold PBS for $5 \mathrm{~min}$ at 1000 r.p.m. The homogenates were then centrifuged at $3000 g_{\max }$ for $20 \mathrm{~min}$. The collected supernatants were recentrifuged at $16000 \boldsymbol{g}_{\max }$ for $10 \mathrm{~min}$. The supernatants were stored at $-20^{\circ} \mathrm{C}$ until further use. Protein concentration 
was measured by the method of Bradford (1976) using the BioRad assay kit (Hercules, CA).

\section{Preparation of uterine wash}

Uterine washings were collected through the vagina after injection of $0.5 \mathrm{ml}$ normal saline into each uterine horn at the ovarian end. The uterine washes were centrifuged at $3000 \boldsymbol{g}_{\max }$ for $10 \mathrm{~min}$. The supernatants were stored at $-20^{\circ} \mathrm{C}$ until further use.

\section{Preparation of endometrial epithelium homogenate}

Rats were killed by cervical dislocation, and their uteri were removed. The epithelium was squeezed towards the opening of the uterine horns and was homogenized in one volume of cold PBS for $3 \mathrm{~min}$ at 1000 r.p.m. The homogenate was then centrifuged at $3000 g_{\max }$ for $20 \mathrm{~min}$. The collected supernatants were recentrifuged at $16000 g_{\max }$ for $10 \mathrm{~min}$. The supernatants were stored at $-20^{\circ} \mathrm{C}$ until further use.

\section{Preparation of endometrial stroma homogenate}

After the removal of the uterus, samples of endometrial stroma were collected by scraping the endometrial tissue towards the opening of the uterine horns. Endometrial stroma homogenate was prepared in the same way as endometrial epithelium.

\section{Preparation of monoclonal antibody and of immunoaffinity column}

The preparation of the DEC 21 monoclonal antibody ( $\mathrm{mAb}$ ) and its immobilization on Eurpergit $\mathrm{C}$ was as described by Halperin et al. (1990). The column was loaded with rat decidual tissue homogenate and then with homogenate of endometrial epithelium, obtained on the day of dioestrus. Specifically bound proteins were then eluted from the $\mathrm{mAb}$-Eupergit $C$ with $1 \mathrm{~mol}$ ammonium acetate buffer $l^{-1}, \mathrm{pH} 10$, and dialysed against PBS.

\section{Polyacrylamide gel electrophoresis}

The electrophoresis was performed with and without $0.6 \mathrm{~mol}$ mercaptoethanol $\mathrm{l}^{-1}$ in the samples (the samples were boiled before application onto the gel) and sodium dodecyl sulfate (Laemmli, 1970). Protein bands were stained with Coomassie brilliant blue R (BioRad).

\section{ELISA}

ELISA using DEC $21 \mathrm{mAb}$ was performed as described by Halperin et al. (1990). Briefly, ELISA plates were coated with the mixture of proteins being examined. The coated samples containing $1 \mu \mathrm{g}$ protein per well in $0.1 \mathrm{ml} 0.1 \mathrm{~mol}$ carbonate buffer $1^{-1}, \mathrm{pH} 9.6$, were incubated for $16 \mathrm{~h}$ at $4^{\circ} \mathrm{C}$. After washing several times with tap water, $\mathrm{mAb}$ was added. After I h at $37^{\circ} \mathrm{C}$, the wells were washed, and to each well $0.1 \mathrm{ml}$ of goat anti-mouse IgG-horseradish peroxidase complex (BioRad), diluted I:3000 was added, and the plates were incubated

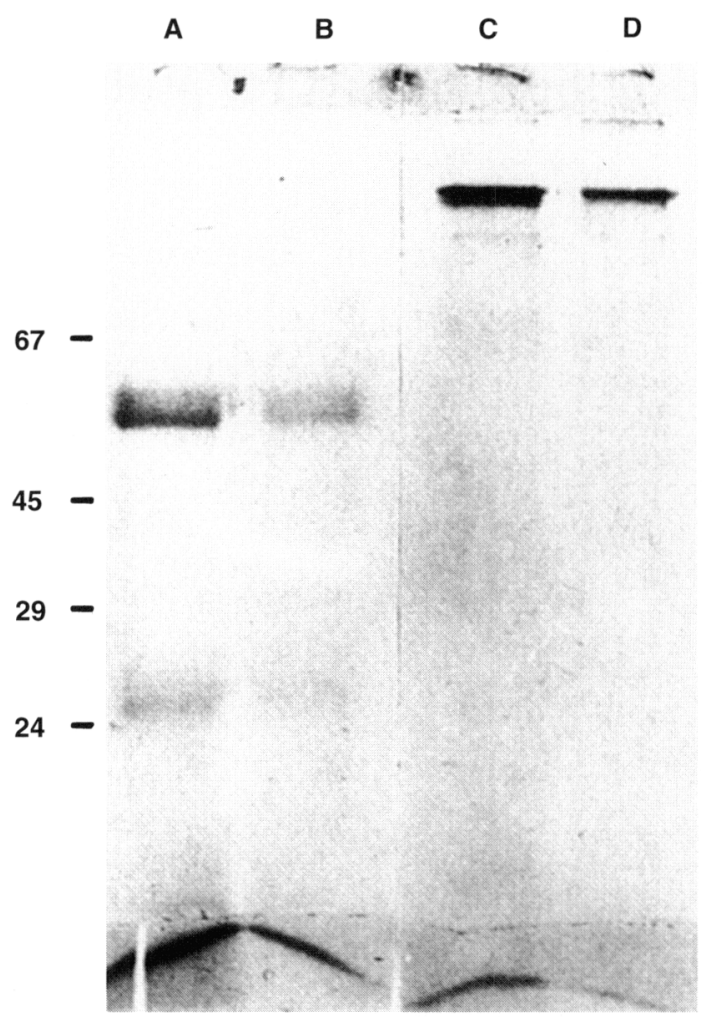

Fig. 1. SDS-PAGE analysis of rat decidua $(A, C)$ and rat endometrial epithelium $(B, D)$ immunoaffinity purified using $m A b D E C 21$, under reducing $(A, B)$ and non-reducing $(C, D)$ conditions.

for $1 \mathrm{~h}$ at $37^{\circ} \mathrm{C}$. After washing, $0.1 \mathrm{ml}$ o-phenylenediamine reagent was added to each well and the colour was allowed to develop. The o-phenylenediamine reagent contained $2 \mathrm{mg}$ 1.2-phenylenediamine $\mathrm{ml}^{-1}$ in $50 \mathrm{mmol}$ sodium citrate buffer $1^{-1}, \mathrm{pH} 5.0$, containing $0.08 \%$ hydrogen peroxide. The concentration was determined by measuring the increase in absorbance at $492 \mathrm{~nm}$ compared with the non-specific absorbance at $405 \mathrm{~nm}$ in an EAR 400 ELISA reader (SLTLabinstruments, Grodig).

\section{Statistical analysis}

The Mann-Whitney $U$ test was used for statistical analysis. A result of $P<0.05$ was considered significant.

\section{Results}

Extracts prepared from rat decidua and rat endometrial epithelium (obtained on the day of dioestrus) were loaded on an immunoaffinity column coupled with $\mathrm{mAb} D E C 21$. The eluted material was analysed by SDS-PAGE under reducing and non-reducing conditions (Fig. 1). Under reducing conditions, both preparations presented as two major bands with apparent molecular masses of $55 \mathrm{kDa}$ and $25 \mathrm{kDa}$, respectively. Under non-reducing conditions, the protein presented as a single major band at $200 \mathrm{kDa}$ in both preparations (Fig. 1), and it was named rat decidua-associated protein (rDP) 200. 


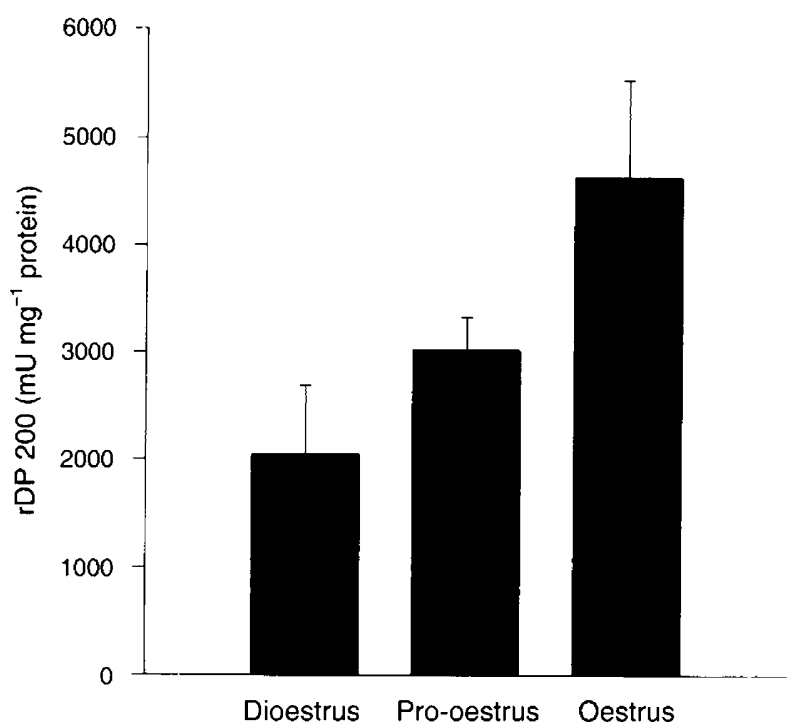

Fig. 2. Concentrations of rat decidua-associated protein (rDP) 200 in uterine washings throughout the oestrous cycle. Values, expressed in $\mathrm{mU} \mathrm{mg}{ }^{-1}$ protein, represent the mean \pm SEM of 5-8 rats per group. Significantly different values $(P<0.05)$ were observed comparing the concentrations of rDP 200 at the different stages of the oestrous cycle.

The concentration of rat protein, similar to the hDP 200, was examined throughout the oestrous cycle (Figs 2 and 3) and on consecutive days, starting the day after the rats mated $\left(\mathrm{L}_{1}\right)$ until the day after blastocyst implantation $\left(L_{5}\right)$ (Figs 4 and 5). The concentration of the protein, recognized by $\mathrm{mAb} D E C 21$, was measured by ELISA in specimens of uterine wash (Fig. 2) and in specimens of endometrial epithelium and endometrial stroma (Fig. 3). The concentration of the specific protein, expressed in arbitrary units, was standardized according to the concentration of total protein, measured by the method of Bradford (1976). The concentration of homologous rat protein in specimens of uterine wash increased significantly throughout the oestrous cycle, reaching maximal values at oestrus (Fig. 2). However, the concentration of rDP 200 in rat endometrial epithelium and stroma differed completely from its concentration in uterine wash. The maximum concentration of the protein in the extract of endometrial epithelium was observed at dioestrus with decreasing concentrations on the following days (Fig. 3a). There were also significant differences in the amount of $\mathrm{rDP} 200$ in rat endometrial stroma throughout the oestrous cycle (Fig. $3 b$ ). The concentrations of homologous rat protein in uterine washings on days $L_{1}-L_{5}$ are shown (Fig. 4). The maximal concentration was found on day $\mathrm{L}_{3}$, increasing significantly from $\mathrm{L}_{1}$ and decreasing significantly towards $\mathrm{L}_{5}$. A similar result was obtained with the extract of endometrial epithelium, although the highest concentration was found on day $\mathrm{L}_{2}$, decreasing significantly towards $\mathrm{L}_{5}$ (Fig. 5a). Rat endometrial stroma demonstrated the highest rDP 200 concentrations on days $L_{1}$ and $L_{5}$ and significantly lower concentrations on $\mathrm{L}_{2}, \mathrm{~L}_{3}$ and $\mathrm{L}_{4}$ (Fig. 5 b). Nevertheless, on days $\mathrm{L}_{1}-\mathrm{L}_{5}$, as well as throughout the oestrous cycle, rDP 200 concentration was significantly lower in endometrial stroma than in endometrial epithelium ( $P<0.05$; Figs 3 and 5 ).

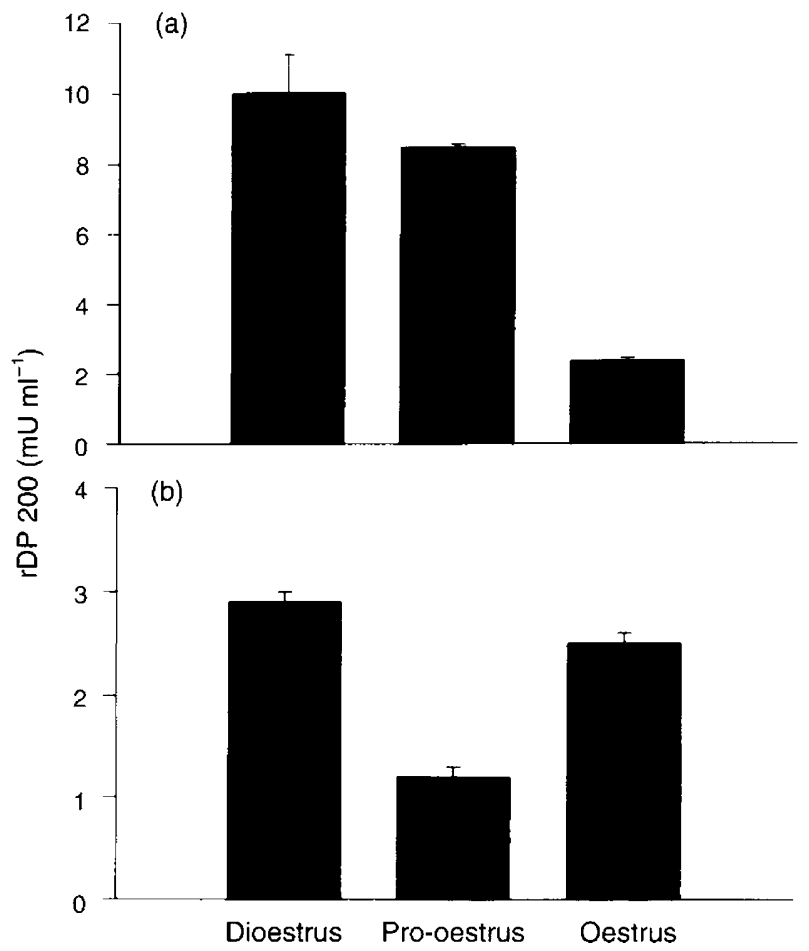

Fig. 3. Concentrations of rat decidua-associated protein (rDP) 200 in specimens of (a) endometrial epithelium and (b) endometrial stroma throughout the oestrous cycle. Values, expressed in $\mathrm{mU} \mathrm{mg}^{-1}$ protein, represent the mean \pm SEM of $5-8$ rats per group. All the values were significantly different $(P<0.05)$, except the concentration of $\mathrm{rDP}$ 200 in endometrial epithelium, which demonstrated no significant difference between dioestrus and pro-oestrus.

\section{Discussion}

The rat has long been used as an animal model with which to study reproductive function (D'Amour and Kiven, 1935; Enders and Schlafke 1967; Batta and Martini, 1975). Therefore, it was chosen to study the possible physiological role of $\mathrm{hDP}$ 200 , identified as a monoclonal rheumatoid factor, in the implantation process.

First, the existence of the protein, immunoaffinity purified by mAb DEC 21, presenting at the same molecular weight in SDS PAGE as the homologous protein in humans was identified in rats. This novel protein, purified from rat decidual tissue and from endometrial epithelium, was named rat decidua-associated protein (rDP) 200.

The next step was to measure the concentration of rDP 200 throughout the oestrous cycle and on the days after the rats mated. Concentrations of rDP 200 were examined in uterine washings, endometrial epithelium and endometrial stroma.

The concentration of rDP 200 was quantified using the single site ELISA instead of double site ELISA, used for measurements of hDP 200 (Golan et al., 1994; Halperin et al., $1995 \mathrm{a}, \mathrm{b}, 1996 \mathrm{~b})$. The single site ELISA measures the presence of protein molecules either single or complexed, while the double site ELISA, using the same mAb for both capture and detection of the hDP 200, measures aggregates containing at least two molecules of hDP 200. The inability of the double 


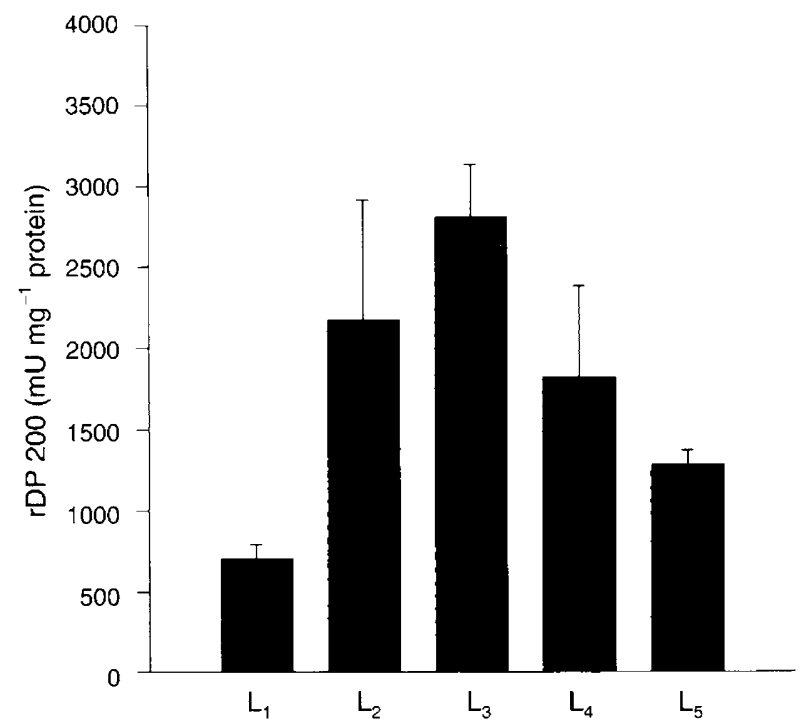

Fig. 4. Concentrations of rat decidua-associated protein (rDP) 200 in uterine washings on consecutive days, starting the day after the rats mated $\left(\mathrm{L}_{1}\right)$ until the day after the blastocyst implantation $\left(\mathrm{L}_{5}\right)$. Values, expressed in $\mathrm{mU} \mathrm{mg}^{-1}$ protein, represent the mean \pm SEM of $5-8$ rats per group. All the values were significantly different $(P<0.05)$, except the concentration of rDP 200 on days $L_{2}$ and $L_{3}$, which demonstrated no significant difference.

site ELISA to evaluate the concentrations of rDP 200 may indicate the existence of the protein in monomers and not in complexes, as was found regarding hDP 200 (Halperin et al., 1996a). This issue has yet to be studied.

The concentration of rDP 200 in uterine washings increased significantly during the oestrous cycle, reaching a maximum value at oestrus. It is possible that the high concentrations of rDP 200 in uterine lumen in the period of mating correlate with the periovulatory peak of hDP 200 in the uterine fluid (Halperin et al., 1996b). The hormone milieu at this stage is compatible with high oestrogen concentration. Rat endometrial epithelium and stroma demonstrate decreasing concentrations of rDP 200 during the oestrous cycle. The discrepancy in distribution of $\mathrm{rDP} 200$ throughout the oestrous cycle, observed when comparing uterine washings with endometrial tissue, may be explained by the fact that rDP 200 is secreted from endometrial tissue into the uterine lumen, and that the secretion is probably oestrogen-dependent.

The oestrogen-controlled accumulation of immunoglobulins ( $\operatorname{IgG}$ and $\operatorname{Ig} A$ ) in rat uterine fluid has been reported and demonstrated to be a local and not a systemic effect (Wira and Sandoe, 1977). Since rDP 200, identified as homologous to hDP 200, is an immunologlobulin existing only in the uterus (Halperin et al., 1995c), it is not surprising to find increasing concentrations of rDP 200 in uterine fluid under oestrogen control. However, according to the present results, demonstrating decreasing concentrations of rDP 200 in endometrium in parallel with increasing concentrations in uterine washings, it can be concluded that secretion or transport and not de novo synthesis of antibodies (Wira and Sandoe, 1977) is more responsible for the oestrogen-influenced immunoglobulin accumulation in uterine secretions.

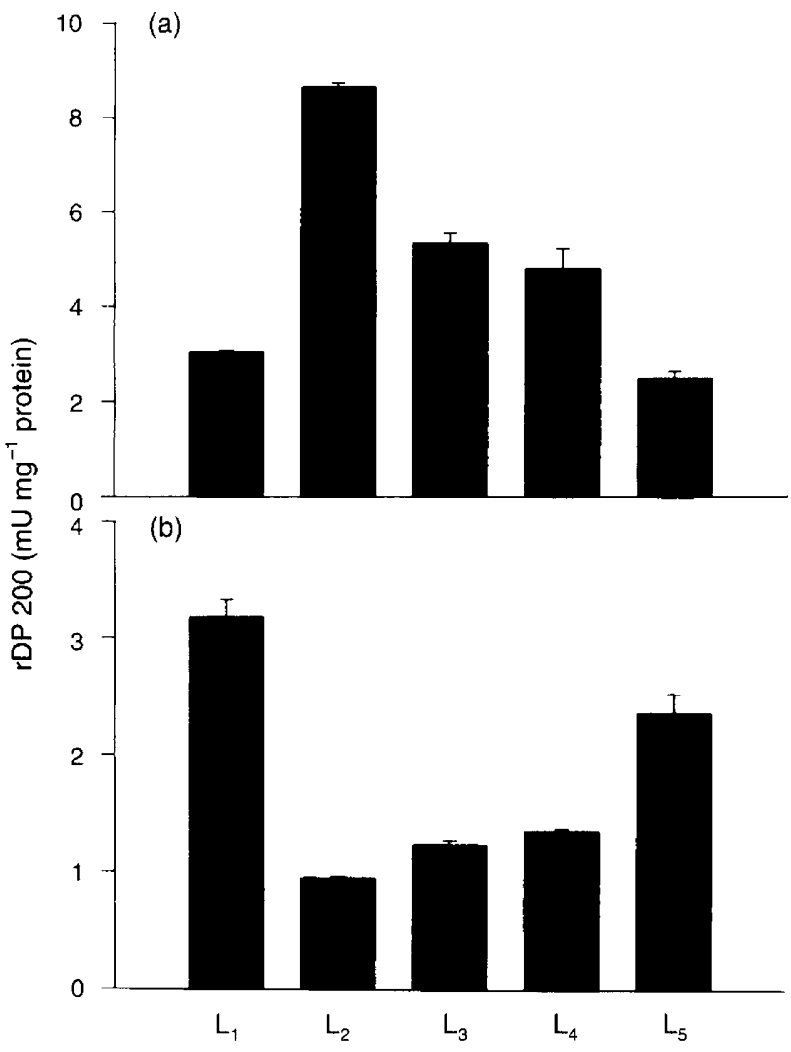

Fig. 5. Concentrations of rat decidua-associated protein (rDP) 200 in specimens of (a) endometrial epithelium and (b) endometrial stroma on consecutive days, starting the day after the rats mated $\left(L_{1}\right)$ until the day after blastocyst implantation $\left(\mathrm{L}_{5}\right)$. Values, expressed in $\mathrm{mU} \mathrm{mg}^{-1}$ protein, represent the mean \pm SEM of $5-8$ rats per group. All the values were significantly different $(P<0.05)$, except the concentration of rDP 200 in endometrial stroma which demonstrated no significant difference between day $\mathrm{L}_{3}$ and day $\mathrm{L}_{4}$.

Assuming that $\mathrm{rDP} 200$ is involved in the implantation process, concentrations were measured on consecutive days, starting the day after the rats mated $\left(\mathrm{L}_{1}\right)$ until the day after blastocyst implantation $\left(\mathrm{L}_{5}\right)$. The maximum concentration of rDP 200 was found on $L_{3}$ in uterine washings and on $L_{2}$ in endometrial epithelium. There is no doubt that the maximum value of rDP 200 in endometrial tissue precedes the one in uterine washings. This finding supports the proposed secretory characteristics of $\mathrm{rDP} 200$ as well as its control by oestrogen (the oestrogen surge takes place on day $\mathrm{L}_{3}$; Shaikh and Abraham, 1969) on accumulation of rDP 200 in uterine fluid. Furthermore, the high concentration of rDP 200 in the uterine lumen a day before the implantation phase, as well as the increasing concentration of rDP 200 in endometrial stroma the day after implantation, adds support to the idea of a relationship between $\mathrm{rDP} 200$ and the implantation process.

The present study supports the use of the rat as an experimental animal model to investigate the possible physiological role of hDP 200 in the reproductive process. Further studies are needed to clarify whether hDP 200 or rDP 200 in rats, identified as monoclonal rheumatoid factor, plays a unique role in the implantation process. 


\section{References}

Batta SK and Martini L (1975) Anti-implantation effect of prostagandins in the rat Prostaglandins 10 1075-1086

Bradford MM (1976) A rapid and sensitive method for the quantitation of protein utilizing principle of protein-dye-binding Analytical Biochemistry 72 $248-254$

D'Amour FE and Kiven N (1935) Harmful effects of certain chemical substances upon the uterus of the rat American Journal of Obstetrics and Gynaecology 29 503-509

Enders AC and Schlafke S (1967) A morphological analysis of the early implantation stages in the rat American Journal of Anatomy 120 185-226

Golan A, Halperin R, Herman A, Hadas E, Soffer Y, Bukovsky I, Caspi E and Ron-EI R (1994) Human decidua-associated protein 200 levels in uterine fluid at hysteroscopy Gynecologic and Obstetric Investigation 38 217-219

Halperin R, Hadas E, Fleminger G, Ovadia $Y$ and Kraicer PF (1990) Identification, immunoaffinity purification and partial characterization of a human deciduaassociated protein Journal of Reproduction and Fertility 88 159-165

Halperin R, Kraicer PF and Hadas E (1994) Human decidua-associated protein hDP 200 appears to be a rheumatoid factor Journal of Reproduction and Fertility $100425-427$

Halperin R, Bracha Y, Schneider D, Maymon R, Kraicer PF and Hadas E (1995a) Human decidua-associated protein hDP 200 in menstrual fluid; comparison between fertile women and women after failed in-vitro fertilization/embryo transfer treatment Human Reproduction 10 324-327

Halperin R, Ron-El R, Golan A, Hadas E, Schneider D, Bukovsky I and Herman A (1995b) Uterine fluid human decidua-associated protein 200 and implantation after embryo transfer Human Reproduction 10 907-910

Halperin R, Ron-El R, Herman A, Schneider D, Hadas E, Bukovsky I and Golan A (1995c) The level of human decidua-associated protein hDP-200 in uterine fluid and serum Gynecologic and Obstetric Observation 39 217-220

Halperin R, Schneider D, Kraicer PF and Hadas E (1996a) Rheumatoid factorassociated high-molecular-weight complexes in the menstrual and amniotic fluids Gynecological and Obstetric Investigation 41 220-223

Halperin R Herman A, Golan A, Hadas E, Schneider D, Bukovsky I and Ron-El R (1996b) Sequential measurements of human decidua-associated protein (hDP) 200 in the uterine fluid during the menstrual cycle American Journal of Reproductive Immunology 35 102-105

Laemmli UK (1970) Cleavage of structural proteins during the assembly of the head of bacteriophage $\mathrm{T}_{4}$ Nature (London) 227 680-685

Shaikh AA and Abraham GE (1969) Measurement of estrogen surge during pseudopregnancy in rats by radioimmunoassay Biology of Reproduction 1 $378-380$

Wira CR and Sandoe CP (1977) Sex steroid-hormone regulation of $\lg A$ and IgG in rat uterine secretions Nature $268534-536$ 